\title{
Parasitic profiling of Japanese quails (Coturnix japonica) on two farms with conventional production system in the Amazon region ${ }^{1}$
}

\author{
Gersonval L.S. Monte ${ }^{2 *}$, Daniel G. Cavalcante ${ }^{3}$ and Jefferson B.S. Oliveira ${ }^{2}$
}

\begin{abstract}
Monte G.L.S., Cavalcante D.G. \& Oliveira J.B.S. 2018. Parasitic profiling of Japanese quails (Coturnix japonica) on two farms with conventional production system in the Amazon region. Pesquisa Veterinária Brasileira 38(5):847-851. Laboratório de Entomologia e Vetores de Doenças Tropicais, Instituto Nacional de Pesquisas da Amazônia, Cx. Postal 478, Coroado, Manaus, AM 69011-970, Brazil. E-mail: gersonval.monte@inpa.gov.br

The health monitoring and management systems of coturniculture can be deemed to be in a developmental phase when compared to the poultry industry. Studies regarding taxonomy and parasitic biology in quails (Coturnix japonica) has not been well conducted in Brazil. Most of the information is available from the autopsy case reports, in many ways the parasitic fauna of quails is still unknown. The aim of this study was to conduct a parasitological research in quails in order to contribute to ameliorate this situation. 31 quails, which were 12 months old, were used for the study. Their carcasses and viscera were sent to the Laboratory of Entomology and Tropical Diseases, INPA, Manaus/AM. The circulatory, nervous, respiratory, digestive and reproductive systems of these were studied separately. No blood parasites were found, however, nine species of endoparasites were registered which were distributed among the classes Cestoda, Nematoda and Protozoa. The helminths were distributed in the duodenum, jejunum, ileum, cecum and oviduct. The cecum was found to be the most parasitized organ and contained a wide range of parasites having three species of protozoa and three species of nematodes. Six morphotypes of Eutrichomastix globosus were recorded, and some morphotypes were hyperparasitized with sporangia Sphaerita sp. in the cytoplasm. A large number of parasites were recorded in this study, as well as the protozoan Blastocystis hominis was first being observed for quail.
\end{abstract}

INDEX TERMS: Parasitic profile, Japanese quails, Coturnix japonica, japanese quail, parasitology, hyperparasitism, ornithopathology, Eutrichomastix globosus, Amazon region, parasitoses.

\begin{abstract}
RESUMO.- [Perfil parasitário de codornas (Coturnix japonica) em duas granjas com sistema convencional de produção na Amazônia.] A coturnicultura conta com um monitoramento sanitário e sistemas de manejo ainda em desenvolvimento quando comparado à avicultura industrial. Pesquisas de taxonomia e biologia parasitárias em codornas (Coturnix japonica) são pouco realizadas no Brasil, sendo a maioria das informações disponíveis referentes a relatos de caso em achados de necropsia, portanto, em muitos aspectos a fauna parasitária
\end{abstract}

\footnotetext{
${ }^{1}$ Received on May 11, 2017.

Accepted for publication on May 29, 2017.

${ }^{2}$ Laboratório de Entomologia e Vetores de Doenças Tropicais, Instituto Nacional de Pesquisas da Amazônia (INPA), Cx. Postal 478, Coroado, Manaus, AM 69011-970, Brazil. *Corresponding author: gersonval.monte@inpa.gov.br

${ }^{3}$ Secretaria Municipal de Meio Ambiente e Sustentabilidade (Semmas), Rua Rubídio 288, Antiga Rua Santa Isabel, Vila da Prata, Mapa, AM 69033-170, Brazil.
}

de codornas é ainda desconhecida. Este trabalho teve por objetivo realizar uma pesquisa parasitológica em codornas em fim de postura. Para pesquisa foram disponibilizadas 31 codornas com idades de 12 meses. As carcaças e suas vísceras foram encaminhadas ao Laboratório de Entomologia e Doenças Tropicais INPA, Manaus/AM. Foram estudados separadamente os sistemas circulatórios, nervoso, respiratório, digestivo e reprodutivo. Das 31 codornas examinadas nenhuma apresentou hemoparasitos, contudo, foram registradas nove espécies de endoparasitos distribuídas entre as classes Cestoda, Nematoda e protozoários. Os helmintos distribuíam-se pelo duodeno, jejuno, íleo, cecos e oviduto. 0 ceco foi o órgão mais parasitado e com maior diversidade de parasitas, sendo três espécies de protozoários e três de nematóides. Foram registrados seis morfotipos de Eutrichomastix globosus, sendo que, alguns morfótipos estavam hiperparasitados com esporângio Sphaerita sp. no citoplasma. Uma grande 
variedade de parasitos foi registrada nesta pesquisa, bem como, o protozoário Blastocystis hominis pela primeira vez sendo descrito para codornas.

TERMOS DEINDEXAÇÃO: Perfil parasitário, codornas, Coturnix japônica, parasitologia, hiperparasitismo, ornitopatologia, Eutrichomastix globosus, Amazônia, parasitoses.

\section{INTRODUCTION}

The rapid growth and diversification of coturniculture for the production of meat and eggs brought along a common problem of intensive production systems, the parasitosis. Coturniculture still has the health monitoring and management systems under developmental phase when compared to the poultry industry, allowing their products to reach the consumer market without proper inspection (Parmar \& Davies 2007, Barrow \& Freitas-Neto 2011).

Studies regarding the taxonomy and parasitic biology in quails (Coturnix japonica Temminck \& Schlegel 1849) have not been coducted widely in Brazil, and the available information is based on the case reports of autopsy findings, or experimental infections (Umar et al. 2014, Bahar et al. 2014). A relevant point about these findings is the absence of clinical manifestations, few macroscopic lesions and low pathogenic cases where massive infections with Cestodas, Nematodes and protozoa pass unnoticed, leaving only direct researches on helminth and injuries during necropsies (Devada \& Jathianesan 1996, Nagarajan et al. 2012).

National coturniculture needs specifically designed research for the description of their species of parasites. To understand the parasitic profile of coturnicultor pole, this study was aimed to describe the parasitic profiling of laying quails created in intensive production system with dual release, posture and slaughter.

\section{MATERIALS AND METHODS}

The experiment was conducted in the Laboratory of Entomology and Vectors of Tropical Diseases, INPA (National Institute for Amazonian Research) Manaus/AM. Necropsies were carried out on 31 quails (Coturnix japonica Temminck et Schlegel, 1849) aged 12 months, which were from two farms situated at $8 \mathrm{~km}$ on Puraquequara road, rural area of Manaus/AM. Initially, the study for ectoparasites and blood parasites was carried through active search and peripheral blood smear. Later, intestinal parasitic infections, macroscopic visceral lesions suggestive of migration of larvae, multiplicative cystic formations and presence of heart, liver, kidney and lung parasites, were also studied.

Each viscera was examined separately in a sterile petri dish with $0.9 \%$ saline solution. Helminths were collected and fixed in AFA solution $70 \%$ alcohol $+40 \%$ commercial formaldehyde $+2 \%$ glacial acetic acid) for 12 hours and then preserved in $70 \%$ alcohol. For identification of helminths, the sample was first clarified with cold $\mathrm{KOH} \mathrm{(10 \% )} \mathrm{for} \mathrm{two} \mathrm{hours.}$

After collecting the helminths, the digestive systems of the quails were washed with $0.9 \%$ saline solution and the obtained contents were examined on slides with cover slips. Protozoan oocysts were photographed for morphological studies, as well as, their structures and dimensions were measured. Positive slides for flagellated forms were fixed with $99.5^{\circ} \mathrm{GL}$ ethanol for three minutes, stained with May-Grünwald-Giemsa diluted in pH 7.2 phosphate buffer solution in the proportion of three drops per ml, and subsequently examined under an optical microscope Nikon Eclipse E-200 with immersion objective (100X). This same procedure was repeated for peripheral blood smears. The illustrations were performed using photomicrographs under a light microscope coupled to a micro camera (ArcSoft WebCam Companion, version 2.0.25.149).

\section{RESULTS}

Nine parasitic species were recorded, which were distributed among classes Cestoda, Nematoda and protozoa (Table 1). There were no ectoparasites and blood parasites in the sampled quails. Helminths were distributed in the duodenum, jejunum, ileum and cecum. The cecum had the greatest diversity of parasites, where six species were recorded, with no difference in the parasitic fauna of the right and left cecum.

The family Heterakidae Railliet et Henry, 1914 was most frequent with an average of 10 parasites per quail, except an infested quail with 113 Heterakidae in the cecum. Heterakidae parasites were observed in $25.8 \%(n=31)$ of the quails and the species found were: Heterakis gallinarum (Schrank, 1788) Freeborn, 1923, Heterakis alata Schneider, 1866 and Odontoterakis multidentata (Baylis, 1944) Skrjabin et Schikhobalova 1947.

Among the 31 quails, $16.1 \%$ had mixed infection of Ascaridia galli Schrank, 1778 and H. gallinarum. 6.4\% $(\mathrm{n}=31)$ quails recorded mixed infection of Choanotaenia infundibulum Bloch, 1779, Capillaria sp. and Eimeria tsunodai. During the in vitro observations of the recently collected $C$. infundibulum from the duodenum, it was observed that hexacanth embryo was released from the egg capsule using their embryonic hooks as a tool to rip the membranes of the capsule, and then as organs of locomotion, providing quick mobility for the embryo in glucose saline solution (Fig.1).

Three species of protozoa were obtained: Blastocystis hominis, Eutrichomastix globosus and Eimeria tsunodai. After staining the slides with Giemsa, specimens of E. globosus hiperparasitised with sporangia of Sphaerita sp. were observed with a ratio of 30/100 (30\%). The sporangia were always located on the periphery of the cytoplasm of E. globosus. No change was observed in wave motion displacement of the parasitized specimens in comparison to the non-parasitized ones, during in vivo observations. Six morphotypes of E. globosus were described, and the short and elongated pyriform morphotypes were observed only in vivo (Fig.2).

Table 1. Taxonomic composition of endoparasites recorded in Coturnix japonica from two farms of rural Manaus, Brazil

$(\mathrm{N}=31)$

\begin{tabular}{cll}
\hline Class & \multicolumn{1}{c}{ Family } & \multicolumn{1}{c}{ Species } \\
\hline Nematoda & Ascarididae & Ascaridia galli \\
& Capillaridae & Capillaria sp. \\
& Heterakidae & Heterakis gallinarum, Heterakis alata \\
& & Odontoterakis multidentata
\end{tabular}

Cestoda Dilepididae Choanotaenia infundibulum

Protozoan Blastocystidae Blastocystis hominis

(Blastocystea)

Protozoan Eimeriidae Eimeria tsunodai

(Coccidiorida)

Protozoan Trichomonadidae Eutrichomastix globosus

(Esporozoa) 

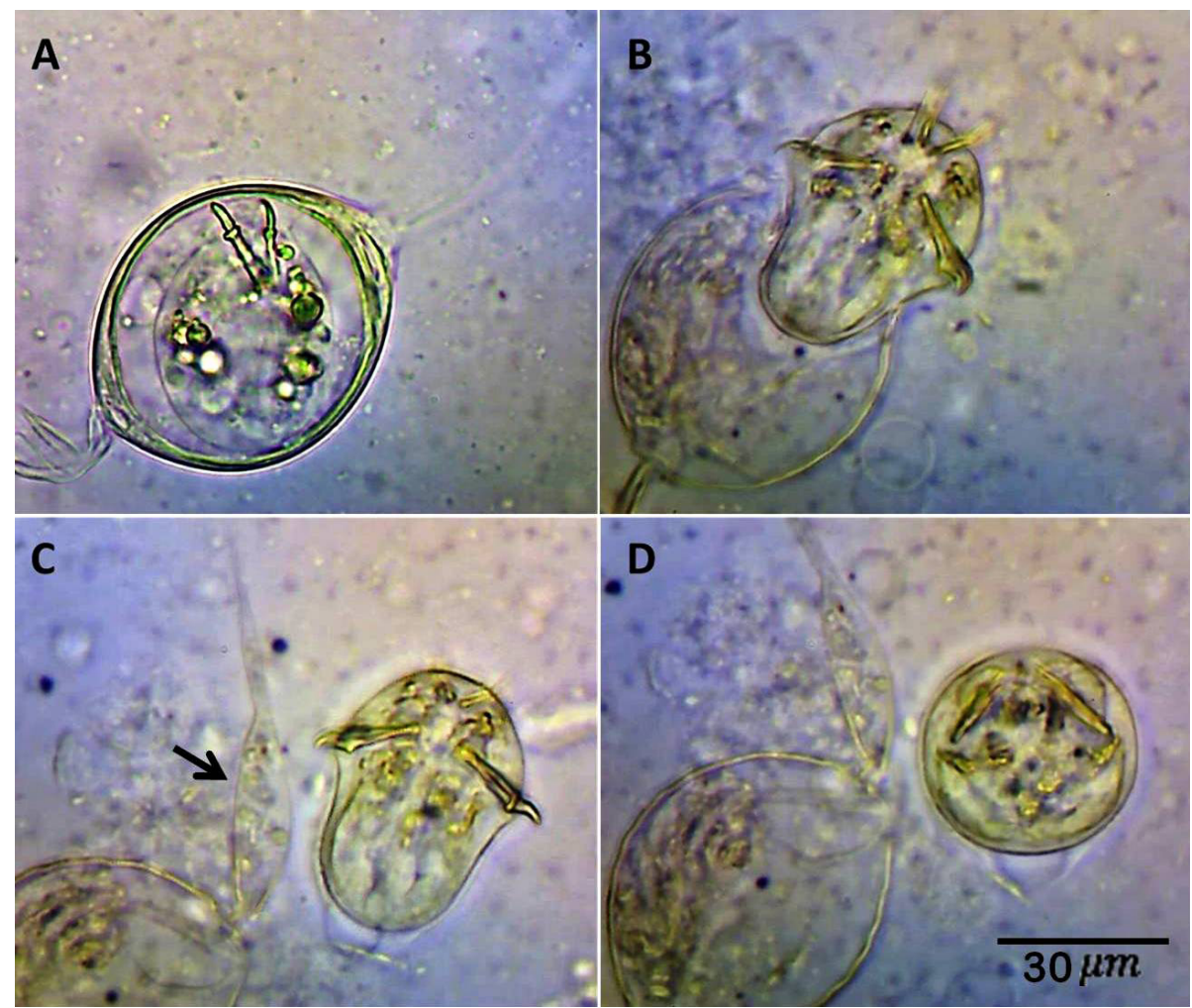

Fig.1. Light photomicrograph of Choanotaenia infundibulum. (A) Egg with fully developed hexacanth embryo. (B) Moment when the embryo breaks the egg wraps. (C) Embryo is already free in the middle, moving with the locking hooks. Arrow indicates polar appendage filamentous characteristics of the species. (D) Progression of embryo assuming globular aspect, characteristic of oncosphere to generate momentum. Optical microscope coupled to a micro camera in 40x.

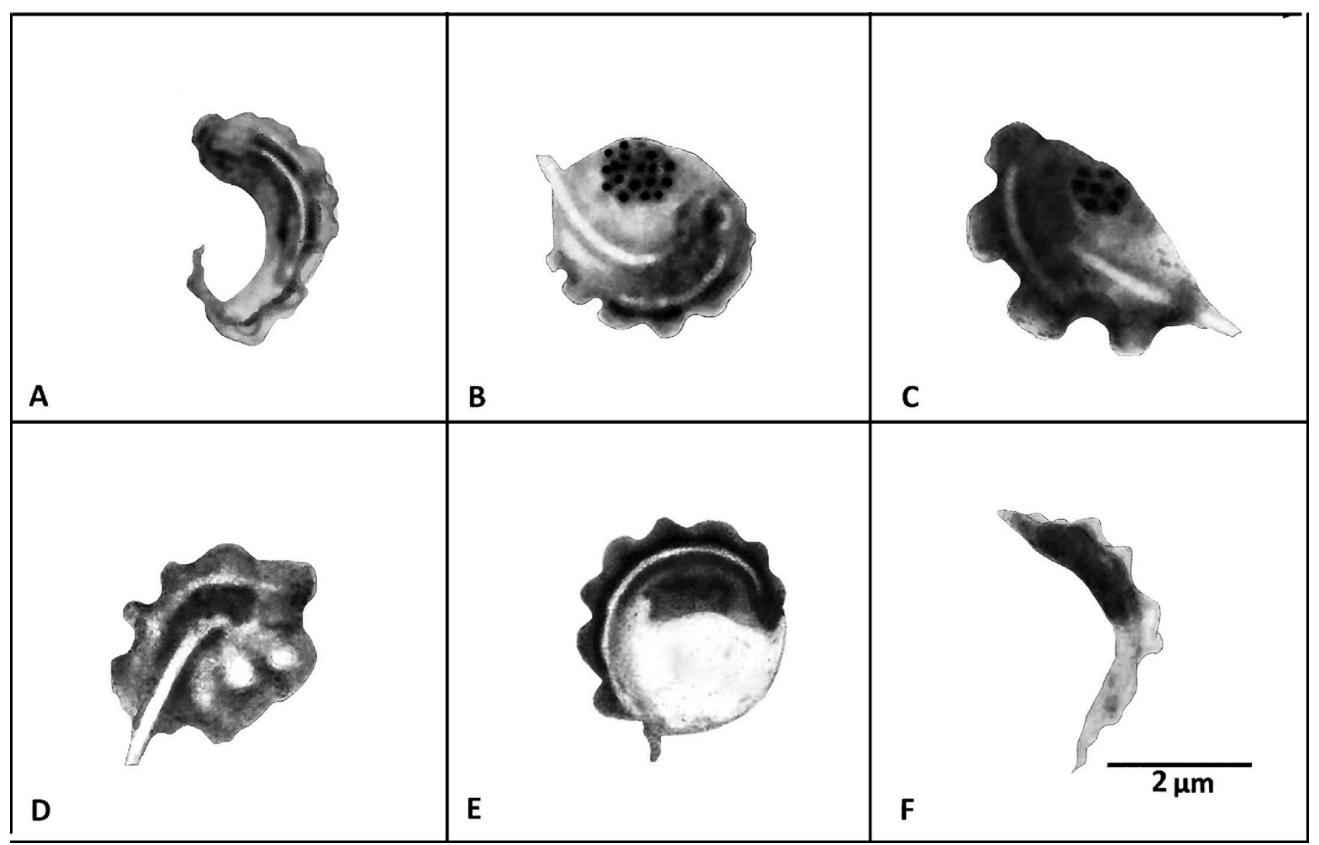

Fig.2. Illustration of morphotypes of Eutrichomastix globosus seen in the washed cecal of Japanese quail. (A) Elongated pyriform morphotype. (B) Rich semiglobulous morphotype in siderophilous granules. Note the hyperparasitism by Sphaerita sp. in the form of rosettes in the cytoplasm. (C) Pyriform morphotype also hyperparasitized by Sphaerita sp. (D) Morphotype without well-defined contours (amoeboid) with well-developed tubular axostyle, refractive and protruding beyond the body. (E) Globular morphotypes with undulating membrane resting neatly on the entire coast. (F) Lancet morphotypes were the most abundant in the stained slides. Illustrations from photomicrographs of light in an optical microscope coupled with a micro camera of objective 100x. 
Four parasitic morphotypes of Blastocystis hominis were registered in 19\% $(\mathrm{n}=31)$ of the quails. The morphotypes were very pleomorphic and measured within $3 \mu \mathrm{m}-15 \mu \mathrm{m}$ with hyaline cytoplasm when observed fresh, sometimes being limited by a thin membrane or sometimes a thicker one containing three to five peripheral nuclei. When stained with Giemsa, the nuclei and the cytoplasm are impregnated eosinofilically and basofilically respectively giving a graduation ring like effect to Blastocystis hominis.

\section{DISCUSSION}

Mixed infections with parasites of families Heterakidae and Ascarididae are frequently found during autopsies of birds. However, ascariasis, an infection by Ascaridia galli, is more commonly reported in young birds, being responsible for cases of severe weakness, weight loss and low oviposition rates, but in some cases infection by A. galli may be missed due to the lack of clinical signs (Permin \& Hansen 1998, Lima et al. 2014).

A. galli infections registered in this research were characteristically restricted to the duodenum and jejunum of quails while those of Heterakidae were restricted to the cecum. Massive infections of Heterakidae can develop similar clinical scenarios as of that with ascariasis: typhilitis, diarrhea, weight loss and low production rates. The Heterakidae identified as Odontoterakis multidentata were easily distinguished from Heterakis gallinarum because of the morphology of the head, the presence of a dent in the esophagus base, arrangement of 14 caudal papillae, relatively short spicules and of equal length and similar to each other (Inglis 1991). While H. gallinarum is endowed with unequal spicules and 13 pairs of caudal papillae (Vicente et al. 1993).

The first natural infection in birds by Choanotaenia infundibulum in Brazil was reported from poultry chickens farms in the State of São Paulo (Sawada 1970) and since then, more infestations has been reported for other groups of birds. C. infundibulum infection is usually mildly pathogenic, and in most cases asymptomatic (Premaalatha et al. 2014). Infected quails found in this study did not have any clinical sign of parasitaemia, but during necropsy exhibited a scenario of catarrhal enteritis that can possibly be associated with cestodes. Observations of in vitro locomotion of hexacanth embryos as recorded in this study, demonstrate the voracity of the parasite inside the host organism.

According to Teixeira et al. (2004) and Mohammad (2012), four species of Eimeria can be found in quails; E. tsunodai Tsutsumi, 1972, E. uzura Tsunoda et Muraki, 1971, E. bateri Bhatia, Pandey et Pande, 1965 and E. fluminensis Teixeira et Lopes, 2002. Based on the specificity of the development site of Eimeria in quails, cecal infection can be associated with $E$. tsunodai, since, according to Tsutsumi (1972), Gesek et al. (2014) this species has almost exclusive development in the cecum, whereas E. bateri, and E. uzura preferably inhabit portions of the duodenum and jejunum respectively (Teixeira et al. 2004, Gesek et al. 2014.).

The flagellates were identified as E. globosus conforming to their biological and morphometric characteristics. Cunha \& Muniz (1927) first recorded flagellated parasites in birds, where four morphotypes were observed in the stool samples (Cunha \& Muniz 1927). This research recorded six morphotypes possibly because not only stool samples, but also the samples of intestinal lavage were analysed. Some specimens of E. globosus were observed to be hyperparasitized with esporangium Sphaerita sp. Occurence of hyperparasitism with Sphaerita sp. are rare in veterinary parasitology. Cunha \& Muniz (1927) reported an occurrence of Trichomonas avium hyperparasitized with corpuscles in the form of rosettes and classified them as Sphaerita sp. However, the report of Cunha \& Muniz (1927) was restricted as they did not mention the impact of hyperparasitism in the population of T. avium.

The enteroparasites described in this study of Blastocystis hominis can be considered highly relevant for public health, since some isolated genotypes were recently reported to be zoonotic and the cause of blastocystosis in immunocompromised patients, AIDS patients and patients in need of hemodialysis. In these cases, $B$. hominis induced a scenario of gastroenteritis with profuse diarrhea associated with weight loss, intestinal cramps, flatulence and possibly fever (Cheng et al. 2006, Dwivedi et al. 2007, Kulik et al. 2008). $B$. hominis is a protozoan that has been rarely recorded during the diagnosis of enteric infections, mainly by the highly varied and fragile morphological characteristics, which does not allow its detection by conventional methods of parasitological examinations (Tan 2004).

\section{CONCLUSIONS}

The findings of Blastocystis hominis, both in the gut and in the oviduct of laying quails, reinforces the necessity to seek for a better understanding of the parasitic fauna in this species, as well as the possible zoonoses, which may be transmitted either by the meat or their eggs.

The report of this rich parasitic fauna in quails in the final approach phase highlights the need for the development of health management practices for regional coturniculture.

Acknowledgements.- The authors are grateful to Dr. José Wallace Sampaio for the assistance in the necropsies.

\section{REFERENCES}

Bahar S., Shahrokh R.B. \& Mosen M. 2014. Study on parasitic infections of quails in Garmsar, Iran. Int. J. Adv. Biol. Biomed. Res. 2(2):262-266.

Barrow P.A. \& Freitas Neto 0. 2011. C. pullorum disease and fowl typhoid, new thoughts on old diseases: a review. Avian Pathol. 40(1):1-13. http:// dx.doi.org/10.1080/03079457.2010.542575. PMid:21331943.

Cheng H.S., Haung Z.F., Lan W.H., Kuo T.C. \& Shin J.W. 2006. Epidemiology of Blastocystis hominis and other intestinal parasites in a Vietnamese female immigrant population in southern Taiwan. Kaohsiung J. Med. Sci. 22(4):166-170. http://dx.doi.org/10.1016/S1607-551X(09)70302-X. PMid:16679297.

Cunha A.M. \& Muniz J. 1927. Estudo sobre os flagellados intestinaes das aves do Brasil. Mem. Inst. Oswaldo Cruz 20(1):19-33. http://dx.doi.org/10.1590/ S0074-02761927000100002.

Devada K. \& Jathianesan V. 1996. Refractoriness of japanese quails (Coturnix coturnix japonica) to Syngamus trachea (Montagu, 1811) infection. J. Vet. Anim. Sci. 20:47-48. 
Dwivedi K.K., Prasad G., Saini S., Mahajan S., Lal S. \& Baveja U.K. 2007. Enteric opportunistic parasites among HIV infected individuals: associated risk factors and immune status. Jpn. J. Infect. Dis. 60(2/3):76-81. PMid:17515636.

Gesek M., Welenc J., Tylicka Z., Otrocka-Domagała I., Paździor K. \& Rotkiewicz A. 2014. Pathomorphological changes in the alimentary system of Japanese quails naturally infected with Eimeria tsunodai. Bull. Vet. Inst. Pulawy 58(1):41-45. http://dx.doi.org/10.2478/bvip-2014-0007.

Inglis W.G. 1991. A revision of the nematode genus Odontoterakis Skrjabin et Schikhobalova, 1947 (Heterakoidea). Syst. Parasitol. 20(1):69-79. http:// dx.doi.org/10.1007/BF00009713.

Kulik R.A., Falavigna D.L.M., Nishi L. \& Araujo S.M. 2008. Blastocystis sp. and other intestinal parasites in hemodialysis patients. Braz. J. Infect. Dis. 12(4):338-341. http://dx.doi.org/10.1590/S1413-86702008000400017. PMid:19030738.

Lima H.J.D., Carvalho L.B., Aquino M.S., Garrido L.I., Camargo M.V.S., Freitas L.C. \& Pacheco R.C. 2014. Frequência de endoparasitos das famílias Eimeriidae e Ascarididae em codornas japonesas na região metropolitana do Vale do Rio Cuiabá/MT. Zootecnia 1(1):7-10.

Mohammad N.H. 2012. A study on the pathological and diagnosis of Eimeria species infection in Japanese quail. Bras. J. Vet. Res. 1(11):318-333.

Nagarajan K., Thyagarajan D. \& Raman M. 2012. Subulura brumpti infection: an outbreak in Japanese quails (Coturnix coturnix japonica). Vet. Res. Forum 3(1):67-69. PMid:25653749.

Parmar D. \& Davies R. 2007. Fowl typhoid in a small backyard laying flock. Vet. Rec. 160(10):348. http://dx.doi.org/10.1136/vr.160.10.348. PMid:17351184.
Permin A. \& Hansen J.W. 1998. The Epidemiology, Diagnosis and Control of Poultry Parasites. FAO, Rome, p.25-27.

Premaalatha B., Chandrawathani P., Jamnah O., Erwanas A.I., Lily Rozita M.H. \& Ramlan M. 2014. Intestinal cestode Choanotaenia infundibulum in chicken. Malaysian J. Vet. Res. 5(2):73-75.

Sawada I. 1970. On the fowl cestode, Choanotaenia infundibulum from Brazil. Bull. Nara Univ. Educ. 19(2):81-82.

Tan K.S. 2004. Blastocystis in humans and animals: new insights using modern methodologies. Vet. Parasitol. 126(1-2):121-144. http://dx.doi. org/10.1016/j.vetpar.2004.09.017. PMid:15567582.

Teixeira M., Teixeira Filho W.L. \& Lopes C.W.G. 2004. Coccidiosis in Japanese quails (Coturnix japonica) characterization of a naturally occurring infection in a commercial rearing farm. Revta Bras. Ciênc. Avic. 6(2):129-134. http:// dx.doi.org/10.1590/S1516-635X2004000200010.

Tsutsumi Y. 1972. Eimeria tsunodai sp. nov. (Protozoa: Eimeriidae): a caecal coccidium of Japanese quails (Coturnix japonica). Jpn. J. Vet. Sci. 34(1):1-9. http://dx.doi.org/10.1292/jvms1939.34.1. PMid:5063025.

Umar H.A., Lawal I.A., Okubanjo 0.0. \& Wakawa A.M. 2014. Morphometric identification, gross and histopathological lesions of Eimeria species in Japanese Quails (Coturnix coturnix japonica) in Zaria, Nigeria. J. Vet. Med. 2014:451945. http://dx.doi.org/10.1155/2014/451945. PMid:26464933.

Vicente J.J., Pinto R.M. \& Noronha D. 1993. Remarks on six species of Heterakid nematodes parasites of Brazilian tinamid birds with a description of a new species. Mem. Inst. Oswaldo Cruz 88(2):271-278. http://dx.doi org/10.1590/S0074-02761993000200015. 